\title{
Community-Oriented Integrated Care
}

\section{Integrated care in the UK: variations on a theme?}

\author{
John Spicer \\ GP Croydon and Head of Primary Care Education, Health Education South London, UK
}

\section{ABSTRACT}

This short review compares the experiences of Scotland and Wales in developing integrated care with those of England, and to some extent Northern
Ireland. It is a companion piece to two other articles published in this issue from Scotland and Wales.
All four countries of the United Kingdom are embarked on slightly different health policy journeys as a result of devolution, politics and philosophical approaches. Of course, the drivers of health policy do not differ very much between those four countries, or arguably between any countries of the developed world; but for us in London the nations of the UK are closest to our hearts and merit the most attention. A comprehensive report on the three devolved nations' integrated care plans has already been written under the auspices of the King's Fund, and an interested reader could do a lot worse than start some further reading here ${ }^{3}$ - indeed, the accompanying article from Wales draws heavily on that source.

Integrated care has no clear cohesive definition or agreed structure yet. Various authors and organisations have described integration between health and social care, between primary and secondary care, and between organisations within primary or secondary care - even the World Health Organization, as far back as 2001, described some early thoughts on the subject. ${ }^{4}$ What seems to unify a coherent meaning of integration is an attempt to make the patient's experience of, and pathways within, the health service[s] less aggravated and more amenable to a good health outcome. In a recent edition, the British Journal of General Practice asked some general practitioner (GP) luminaries to describe what integration should look like for acutely ill children, the frail elderly, multimorbid people, etc. ${ }^{5}$ Not surprisingly, all the authors looked to easier pathways of care, shared records, evidence-based care, care plans and co-location, among other things.

So how are these laudable aims addressed in our four nations?
In one accompanying article, Bruce and Parry describe a quite explicit Scottish aim to integrate health and social care, using a philosophy of partnership as a vehicle of change. Significantly, a statute was passed in 2014 to advance this integration, which included a modus operandi to bring it about. Although the last English statute to bring about health service reform (the Health and Social Care Act 2012) did contain many references to integrated care, including the duty of the Secretary of State to advance its cause, it is arguable whether the Act can actually bring it about, favouring as it does a competitive basis to the provision of health care. ${ }^{6}$

Northern Ireland has had, at least in theory, integrated health and social care for the last 40 years, although such integration has really only been achieved in some specified areas: learning disability, mental health and elderly care services. To complete the task, it is claimed the types of debate now going on elsewhere in the UK would need to be had. As Lewis highlights, Wales, like England, is not particularly advanced in the integration of social care, other than some specific local examples which are paving the way forward.

Recent developments in Manchester may suggest a degree of political jump-starting on a regional basis. A Memorandum of Understanding is now available, ${ }^{7}$ which describes in initial terms a coherent and cohesive region of England, unifying the budgets for health and social care in order to drive up the quality and efficiency of both. Immediate political reaction was mixed.

We should remind ourselves that the key difference between England and the rest of the UK (ROK; a term coined in the recent Scottish referendum) is the purchaser-provider split, or lack of it. Scotland and 
Wales abolished their 'commissioner-provider' divide when they gained devolution powers that included health, whereas England amplified its own divide via the agency of the 2012 Act. Northern Ireland does have a divide, although according to the King's Fund, this has not contributed to the integrated care agenda. In fact, Northern Ireland now has one large commissioning agency and a small number of provider trusts covering all aspects of care - competition would appear to be absent. At nearly two million population, Northern Ireland is most directly comparable with a sector of London. Wales too has unified health-planning authorities - local health boards - that uncannily resemble the now defunct English health authorities.

So what England retains in its own version of the commissioner-provider system is a notion of competition, or perhaps the illusion of it. Such competition may only be possible in large conurbations where there is a diversity of providers able to provide to a commissioned specification. Perhaps London would be one example of this. However, we might sensibly challenge whether a competitive system of health and social care commissioning can bring about the outcomes described above, or whether a more collaborative approach might pay better dividends in this area. Implicitly, the London Health Commission in its report on the development of Londoners' health last year favoured collaboration over competition in a future move to integrated care, citing 'complex contracting processes' as a constraint. ${ }^{8}$ The three devolved nations seem to agree.

What cannot be ignored in any discussion of integrated care are the contextual issues common to the UK as a whole. There is no sign of any relief in budgetary constraint, handily abbreviated to 'austerity'. It is indeed tempting to badge integrated care as a means of operating more cheaply than hitherto, though a recognition of the need to 'spend to save' is explicit in Scotland's plans, and referred to by the King's Fund in another analysis of integrated care as a key determinant. ${ }^{9}$

Allied to such a driver is the continuing need to shift care from hospital to primary care. The reasons for this are not just financial, because of the high unit cost of secondary care, but also the oft-cited preference of patients to be treated in or close to their own environments. Such a move necessitates primary and community workforce development, linked ICT support and the avoidance of silo working.

This Journal has considered integrated care before of course, most notably in an interview with Professor Lord Darzi in 2014 and a follow-on commentary in 2015. ${ }^{10,11}$ Among other things, the articles described the negative impact of inordinate organisational change in the NHS, marketisation of commissioning and financial constraint. As previously noted, Wales, Scotland and Northern Ireland are less vulnerable to the first two issues, and so if they constrain integrated care development they are better placed than we are in London. However, London does have a coherent geography, now managed by three local area teams who succeed a unified strategic health authority, which might empower service reconfiguration. This may be evident in the recent London Primary Care Transformation plans, currently wending their way through the corridors of power. ${ }^{12}$ Darzi and Ferlie also champion the virtues of experimentation in service redesign and provision - something less explicit in the plans of Wales and Scotland but implied in both accounts published here.

All four areas' accounts are at their most intelligible when concrete accounts of patient experience are used to describe a future integrated service. For example, to consider what is arguably our greatest service need, that of the complex elderly patient group, in a little more detail:

- The Gwent Frailty programme, described as 'leading edge' in Wales aims to bring together a shared resource from health, social care and third sector budgets in order to prevent admission, provide continuity of care and name responsible providers - laudable aims all. The programme started in 2011 and has exhibited promise, though 'tensions' are noted between stakeholders.

- The regional Innovations in Medicines Management initiative in Northern Ireland is primarily tackling good drug use in the elderly and multimedicine population by working across traditional primary/secondary care divides. Essentially another version of integrated care, this is producing cost savings and better medicine use.

- 'Reshaping care for older people' is an ambitious Scottish plan to change the landscape of elder care. An element of the plan is the use of a change fund to underpin major structural and process change in the care of this group 'supported to enjoy full and positive lives in their own homes or homely settings'.

Each of these developments, among others, is provided for by the differing high-level levers described in the accompanying articles. The London Health Commission report contained many things of import, but is fairly short on care of the elderly as a special group. Perhaps we could use the good example of our fellow UK nations to advance integrated care and provide better for this population than we do. If nothing else, this integrated care agenda will require practitioners to work much more as part of systems, be they federations, local networks or similar. New learning is inevitably called for as part of this profound change. To some extent it is already happening at a local level within London, and certainly primary care is well advised to engage with these models and processes as they emerge. ${ }^{13}$ 


\section{REFERENCES}

1 Bruce D and Parry B (2015) Integrated care: a Scottish perspective. London Journal of Primary Care 7:44-8.

2 Lewis M (2015) Integrated care in Wales: a summary position. London Journal of Primary Care 7:49-54.

3 Ham C, Heenan D, Longley M and Steel DR (2013) Integrated care in Northern Ireland, Scotland and Wales: Lessons for England. King's Fund: London.

4 Gröne $\mathrm{O}$ and Garcia-Barbero M (2001) Integrated care: a position paper of the WHO European office for integrated health care services. International Journal of Integrated Care 1:e21.

5 Jones R, Van den Bruel A, Gerada C, Hamilton W, Kendrick T and Watt G (2015) What should integrated care look like...? British Journal of General Practice 65(632):149-151.

6 Health and Social Care Act (2012) www.legislation. gov.uk/ukpga/2012/7/pdfs/ukpga_20120007_en.pdf (accessed 24/04/15).

7 Greater Manchester Health and Social Care Devolution - Memorandum of Understanding. www.agma.gov.uk/ cms_media/files/mou.pdf (accessed 25/04/15).

8 London Health Commission (2014) Better Health for London. www.londonhealthcommission.org.uk/wp-
content/uploads/Better-Health-for-London-InteractiveSummary-Report.pdf (accessed 03/03/15).

9 Ham C and Walsh N (2013) Making Integrated Care Happen at Scale and Pace. King's Fund: London.

10 Thomas P (interviewer) (2014) The Professor Lord Darzi interview. London Journal of Primary Care 6:111-16.

11 Ferlie E (2015) Commentary on text of interview with Professor Lord Ara Darzi: 'Desirable? Yes; but is it achievable?' London Journal of Primary Care 7:2-5.

12 Transforming Primary Care in London - a strategic commissioning framework. www.england.nhs.uk/london/ wp-content/uploads/sites/8/2015/03/lndn-prim-caredoc.pdf (accessed 10/04/15).

13 Southwark and Lambeth Integrated Care. www. slicare.org/ (accessed 10/04/15).

\section{ADDRESS FOR CORRESPONDENCE}

Email: john.spicer@southlondon.hee.nhs.net

Submitted April 2015; revised April 2015; accepted May 2015

\section{Appendix}

\section{Summary of systems}

\begin{tabular}{|c|c|c|c|c|}
\hline England & Scotland & Wales & Northern Ireland & \\
\hline $\begin{array}{l}\text { Population } 2011 \\
\text { (millions) }\end{array}$ & 53 & 5.3 & 3 & 1.8 \\
\hline 'Market' health care & Overt & Absent & Absent & Theoretical \\
\hline $\begin{array}{l}\text { Joint health and } \\
\text { social care } \\
\text { commissioning }\end{array}$ & Planned & Planned & Emerging & In place \\
\hline $\begin{array}{l}\text { Health } \\
\text { commissioning }\end{array}$ & $\begin{array}{l}\text { Clinical } \\
\text { commissioning } \\
\text { groups and NHS } \\
\text { England }\end{array}$ & $\begin{array}{l}\text { Health Boards } \\
\text { commission all }\end{array}$ & $\begin{array}{l}\text { Local Health } \\
\text { Boards commission } \\
\text { all }\end{array}$ & $\begin{array}{l}\text { Unified Health and } \\
\text { Social Care Board }\end{array}$ \\
\hline
\end{tabular}

